\title{
Impact of Water Body for Pilgrim Cities in India
}

\author{
Vishnu Kumar Pahariya ${ }^{1 *}$, Anjali S. Patil ${ }^{2}$ \\ ${ }^{1}$ Student, Department of Architecture \& Planning, Madhav Institute of Technology and Science, Gwalior, India \\ ${ }^{2}$ Associate Professor, Department of Architecture \& Planning, Madhav Institute of Technology and Science, \\ Gwalior, India \\ *Corresponding author: vishnupahariya@gmail.com
}

\begin{abstract}
The mythological place India is blessed with the sacred streams, little and enormous water bodies.it is likewise adobe of numerous exceptional holy people, strict and Spiritual Leaders. Significant pilgrims in India are Haridwar, Gangotri, Yamunotri, Prayagraj, Char dhams, Dwarika, Puri, Rameswaram and Badrinath, twelve Jyotirlingas, Chitrakoot, varanshi, ayodhya, etc are on the bank of sacred waterways. These pioneer cities and its sacred spots pulls in a mass of explorers and pilgrims from different pieces of the nation and around the world. Because of its devotion, there is a huge increment in floating and urban populace. These pilgrim's explorers during journeys every year which has a high potential to impact the urban condition in these blessed destinations. In pilgrimage, impacts are influenced by festival and are limited over time and space such as "chhath pooja" in Bihar, Jharkhand, Uttar Pradesh and Nepal, Kumbha and Ardh kumbhs various parts of India etc. are associated directly with water bodies. Urban preservation is very important in the case of pilgrim cities because of the its mythological values. These pilgrim city determines, it is not just in its place of workshop be it temple, church etc., but a built heritage related and in the layout and design of the cities, some pilgrim cities are designed on the design principals of Vedic Principles. The regional setting in which the cities are placed and its relationship with water bodies and other heritage features. This paper identifies the issues and challenges in the core of pilgrim cities, which is water surrounding place of worships associated with different rituals which reflect new gravities on the urbanization.it is based on literature study and case study approach.
\end{abstract}

Keywords: Impact of water body, Pilgrim cities, Urban preservation, Urbanization.

\section{Introduction}

Greek philosopher Plato said: "A city is place where man had a common life for a noble end".

While a river streams, it cares many human activities and their habitation. All over the world river valleys have been cradles of civilization because all the major civilizations -Egypt on the Nile, Mesopotamia on the Tigris and Euphrates, Mohenjodaro and Harappa on the Indus flourished along the river banks. Due to their importance to human civilization, rivers have been held sacred and worshipped in India since time immemorial. The riverfront development has played a key role in the life of the many cities. Like veins and arteries, rivers and canals are channels of connection and communication. In India pilgrim place are associated with water and its use in their every worship.

\section{Conceptual Terms}

\section{A. Pilgrimage}

The term pilgrim now commonly denotes a religious journey, Now-a-days use of the terms pilgrim and tourist, recognizing the former as a religious traveller and the latter as a vacationer, is a culturally constructed polarity that covers the motives of the travellers search.

\section{B. Difference between Tourist and pilgrim}

A "tourist" is a person who travels or visits a place for pleasure but pilgrim a person who journeys (yatras), specifically a long distance, to some holy place as an act of religious devotion.

\section{Religious Tourism}

The concept of religious tourism has arisen alongside changes that have occurred in modern society regarding patterns of behavior and attitudes towards religion.

\section{Role of Water in Urban Planning}

Basic necessity of human and its settlement is being is food, shelter and clothing these necessity is directly associated with water, world History of human settlements says that every civilization was along the river and its tributaries. The river ganga have its own importance with its own right. Sometimes the "land and river" both respected as "MOTHER" in spiritual way. For land it's called as "MATRUBHUMI".

Following are the major role of water in urban context.

- $\quad$ Played a major role in sustaining the city itself.

- Provide water, support natural processes - like flood prevention and provide habitats for plants and animals.

- Provides economic growth through water transportation systems etc.

\section{Advantage of Water in Pilgrim City}

\section{A. Socio cultural connects communities:}

water connects every pilgrim. In pilgrimage, impacts are influenced by festival and are limited over time and space such 
as "chhath pooja" in Bihar, Jharkhand, Uttar Pradesh and Nepal, Prayagraj, Nashik and Ujjain Kumbha and Ardh kumbhs various parts of India etc. are associated directly with water bodies.

\section{B. Socioeconomic importance of the pilgrim city}

The religious institutions, holy sites are often surrounded by religiously orientated businesses and facilities, such as souvenir shops, travel agencies, hotels and even hospitals, providing employment for the host community.

\section{Research importance}

It provides research opportunities for majorly stockholders of city developer such as urban planners, architects, engineers, researchers of various fields, and various other institutions.

\section{Heritage importance}

Every Pilgrim city has its unique tangible and intangible heritage values which create memorable impact of every visitor. Non profitable Institutions like INTACH (The Indian National Trust for Art and Cultural Heritage), ASI (Architectural survey of India) have major role for conservation of heritage of pilgrim cities.

\section{E. Environmental importance}

Naturally water body provides not only provides thermal comforts but also minimize urban heat islands Helps increments in natural vegetation.

\section{Case Study of Varanasi}

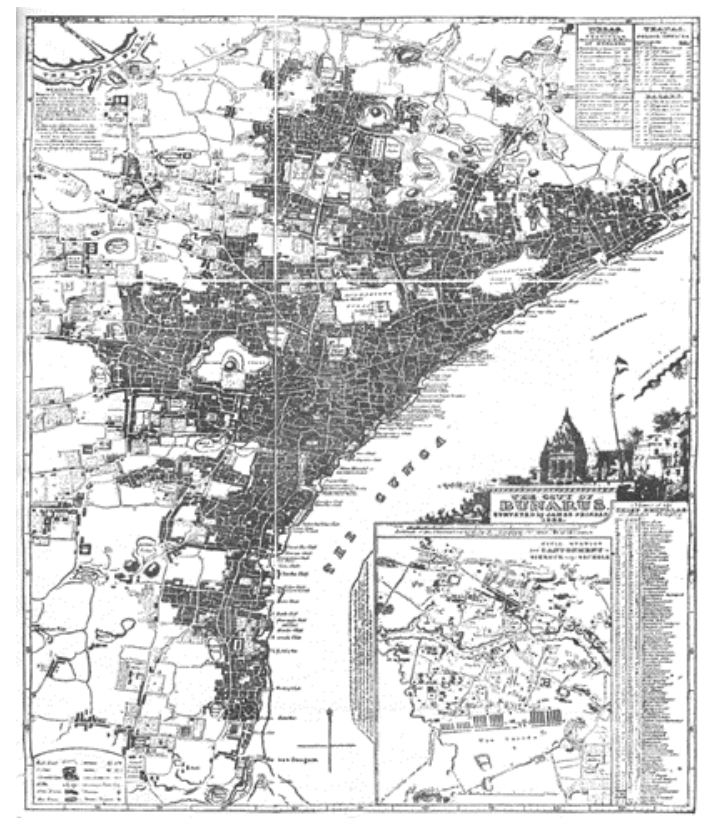

Fig. 1. Map of Varnashi city along river ganga

- Varanasi (Benares) or Kashi, is a city on the banks of the river Ganga in Uttar Pradesh.

- Varanasi is located between the Ganges streams with two rivers: The Varuna and the Assi stream.
- Located in the Indo-Gangetic Plains of North India, the land is very fertile because low level floods in the Ganges continually replenish the soil.

- It is considered one of the oldest continuously inhabited by human since $800 \mathrm{BCE}$ and the ancient city in India.

- Hindu legend has it that Varanasi is the centre of the universe, the first city created by the gods on Earth, and it is certainly true that it was already an old city when Rome was created.

Table 1

Annual tourist visits during 2002-2005

\begin{tabular}{|c|c|c|c|c|c|c|}
\hline \multicolumn{2}{|c|}{ Year (Jan to Dec.) } & 2002 & 2003 & 2004 & 2005 & \begin{tabular}{|l|}
2006 (Till \\
march'06)
\end{tabular} \\
\hline \multirow{3}{*}{ Varansi } & Domestic & $25,88,178$ & $27,01,716$ & $28,09,422$ & $30,49,980$ & $9,69,909$ \\
\hline & Foreign & 98,765 & $1,08,017$ & $1,41,328$ & $1,43,993$ & 44,000 \\
\hline & Total & $26,86,943$ & $28,09,733$ & $29,50,750$ & $31,93,973$ & $10,13,909$ \\
\hline \multirow{3}{*}{ Sarnath } & Domestic & $4,39,099$ & $4,45,334$ & $5,04,833$ & $5,72,650$ & $1,51,250$ \\
\hline & Foreign & $1,47,173$ & $1,72,872$ & $1,99,413$ & $2,01,725$ & 49,102 \\
\hline & Total & $5,86,272$ & $6,18,206$ & $7,04,246$ & $7,74,375$ & $2,00,352$ \\
\hline \multirow{3}{*}{ Total } & Domestic & $30,27,277$ & $31,47,050$ & $33,14,255$ & $36,22,630$ & $11,21,159$ \\
\hline & Foreign & $2,45,938$ & $2,80,889$ & $3,40,741$ & $3,45,718$ & 93,102 \\
\hline & Total & $32,73,215$ & $34,27,939$ & $36,54,996$ & $39,68,348$ & $12,14,261$ \\
\hline
\end{tabular}

Following fig. 2 and 3 shows development taken place along water body for pilgrim city Varanasi.

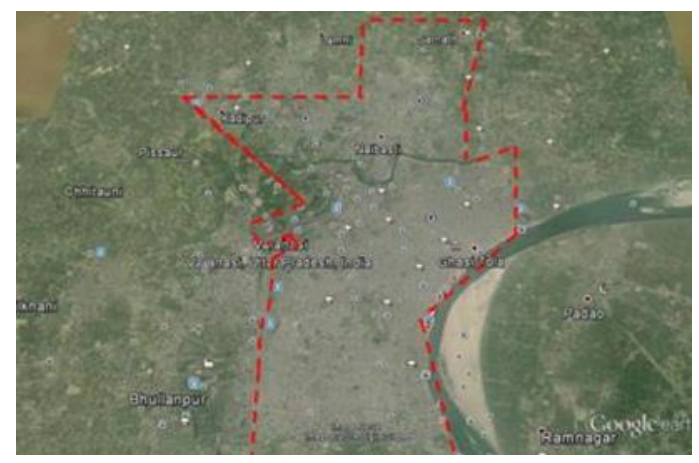

Fig. 2. Old settlements along river

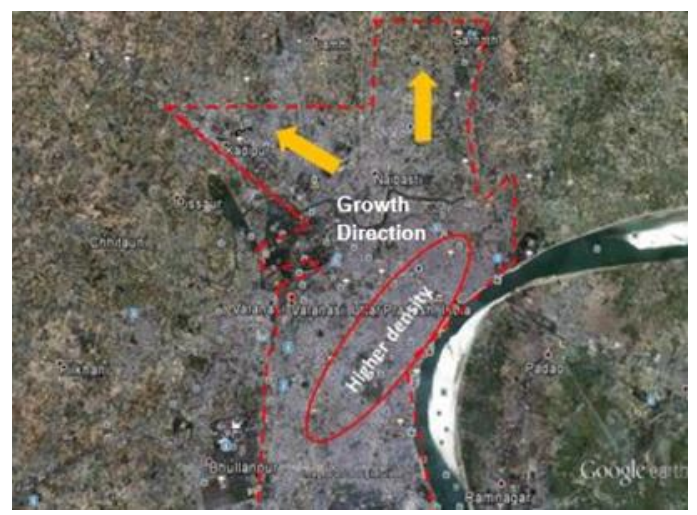

Fig. 3. Infrastructure development along river ganga

\section{A. Influence due to pilgrim}

The following table represents category-wise number of units, capital investment and employment of major industries in Varanasi. (Fig. 4 and Table 2) Floating population not only 


\section{IJRESM journals.resaim.com/ijresm | ISSN (Online): 2581-5792 | RESAIM Publishing}

generates economy but it's also increase employment and job opportunities.

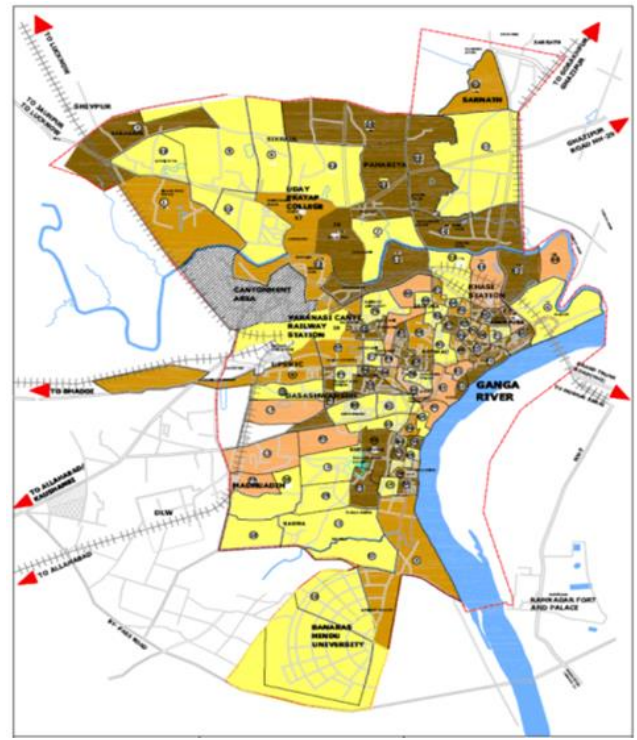

Fig. 4. Industrial development in varanashi

Table 2

Industries which are dependent on pilgrims

\begin{tabular}{|c|c|c|c|c|}
\hline S.NO & TYPE OF INDUSTRY & NUMBER OF UNITS & $\begin{array}{l}\text { INVESTMENT } \\
\text { (LAKH RS.) }\end{array}$ & EMPLOYMENT \\
\hline 1 & Agro-based & 141 & 14.10 & 706 \\
\hline 2 & Cotton Textile & 515 & 50.61 & 2576 \\
\hline 3 & $\begin{array}{l}\text { Wooden, silk and artificial thread-based } \\
\text { clothes }\end{array}$ & 813 & 80.40 & 4076 \\
\hline 4 & Jute and jute-based & 25 & 0.25 & 100 \\
\hline 5 & Readymade garments \& embroidery & 480 & 48.035 & 2401 \\
\hline 6 & Wood/wooden-based furniture & 485 & 40.85 & 2426 \\
\hline 7 & Paper and paper products & 40 & 20.80 & 201 \\
\hline 8 & Leather-based & 25 & 10.20 & 126 \\
\hline 9 & Chemical/chemical-based & 430 & 30.10 & 2151 \\
\hline 10 & Rubber, Plastic \& petro- based & 60 & 25.15 & 301 \\
\hline 11 & Mineral-based & 310 & 20.20 & 1551 \\
\hline 12 & Metal-based (Steel Fab.) & 415 & 30.15 & 2076 \\
\hline 13 & Engineering units & 510 & 40.10 & 2551 \\
\hline 14 & $\begin{array}{l}\text { Electrical machinery and transport } \\
\text { equipment }\end{array}$ & 90 & 5.20 & 451 \\
\hline 15 & Repairing \& servicing & 978 & 128.21 & 5073 \\
\hline
\end{tabular}

Table 3

List of festivals which is dependent on the water

\begin{tabular}{|l|c|c|}
\hline Festivals & Venue & Period of Occurrence \\
\hline Paush Poornima & Ghats & January \\
\hline Makar Sankranti & Ghats & January \\
\hline Mauni Amavasya & Ghats & January/February \\
\hline Magh Poornima & Ghats/Ravidas Mandir & February \\
\hline Ganga Water Rally & Ghats & February \\
\hline Dhrupad Mela & Tulsighat & March \\
\hline Mahashivaratri & Ghats \& temples & March \\
\hline Navratra (Chaitra) & Ghats / Temples & April \\
\hline Ram Navami & Tulsi Manas Mandir \& Ghats & April \\
\hline $\begin{array}{l}\text { Sankat Mochan } \\
\text { Festival }\end{array}$ & Sankat Mochan Mandir & April \\
\hline Buddha Poornima & Sarnath & May \\
\hline $\begin{array}{l}\text { Ganga Dussehra } \\
\text { Ramlila, Ramnagar }\end{array}$ & Ghats & June \\
\hline Dhanush Yagya & Ramnagar & September-October \\
\hline Ram Vivah & Ramnagar & September \\
\hline Nakkataiya & Ramnagar & September \\
\hline Pitra Visarjan & Ghats & September \\
\hline Navaratra(Ashwin) & Ghats \& Temples & September \\
\hline Vijaya Dashmi / Dussehra & Ramnagar D.L.W Vidyapeeth & October \\
\hline
\end{tabular}

Source - UP Tourism Department, Varanasi and Ministry of Tourism, Government of India

\section{Risk Involved for Pilgrim City}

- Rapid air, land and water pollution due to floating population.

- Huge variation in infrastructure demand due to large floating population.

- Major dependence of city on religious tourism for economic activity.

- Requiems of Variable service infrastructure facility like STP, roads, public amenities etc.

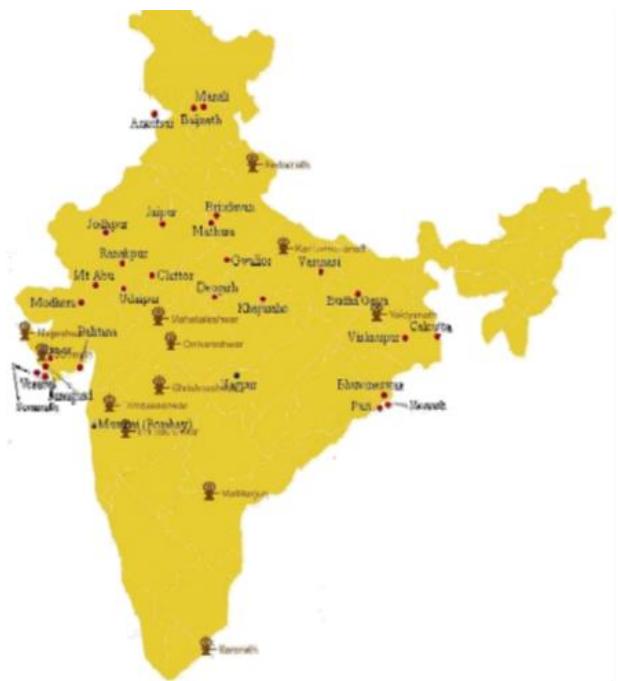

Fig. 5. Major pilgrim cities which are along water pilgrimage rejuvenation and spiritual augmentation drive (Prasad)

\section{Conclusion and Way Forward}

Conservation of pilgrim city is very important issue along with water bodies and its resources as foot of floating population is increasing rapidly as we have limited natural resources. We have to follow some solutions. These are following.

1. Increment of temporary infrastructure like ghaats, peepa bridges, asthi visarjan spots and their service corridors.

2. Increment of river tourism as ferry been started between prayagraj to varanshi in 2019 kumbh of prayagraj.

3. Increment of temporary tents, pandaals, public toilet, hospitals, shops, police stations, CCTV camera points with integrated command and control center.

4. Holistic approach with state and central's policy making and their implementation.

5. Following fig. 6 is shows, how we have to use the culture of water bodies as sustainable development in pilgrim cities.

Water bodies in pilgrim cities are our heritage, we have to practice for its conservation. We also called our river ganga as "maa ganga". 
Volume-3, Issue-9, September-2020 journals.resaim.com/ijresm | ISSN (Online): 2581-5792 | RESAIM Publishing

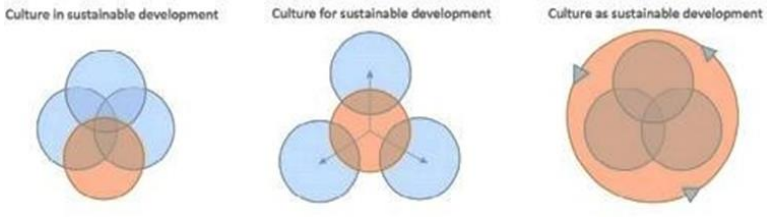

Fig. 6. Integration of culture in sustainable development

\section{References}

[1] http://www.itpi.org.in/journals

[2] CDP of varanshi.

[3] S. Vijayanand, "Socio-economic impacts in pilgrimage tourism."

[4] Year wise Tourist Statistics,

http://www.uptourism.gov.in/pages/top/about-up-tourism/year-wisetourist-statistics 